\title{
Tolerance of Macrophytes and Grasses to Sodium and Chemical Oxygen Demand in Winery Wastewater
}

\author{
N.S. Zingelwa ${ }^{1 *}$ and J. Wooldridge ${ }^{2}$ \\ (1) ARC Infruitec-Nietvoorbij, Private Bag X5026, Stellenbosch 7599, Republic of South Africa. Zingelwan@arc.agric.za \\ (2) ARC Infruitec-Nietvoorbij, Private Bag X5026, Stellenbosch 7599, Republic of South Africa. Wooldridgej@arc.agric.za
}

Submitted for publication: June 2009

Accepted for publication: July 2009

Key words: chemical oxygen demand, Juncus acutus, Pennisetum clandestinum, Scirpus maritimus, sodium, Typha latifolia, Vetiveria zizanioides, winery wastewater

\begin{abstract}
Winery wastewater often contains elevated concentrations of sodium (Na), and has a high chemical oxygen demand (COD). In constructed wetlands, Na may be removed through phytoremediation by such macrophytic plants as Typha latifolia, Juncus acutus and Scirpus maritimus. The relative abilities of these plants to absorb Na, and to tolerate high COD wastewaters was determined in a glasshouse pot trial. Also tested were Pennisetum clandestinum (Kikuyu) and Vetiveria zizanioides (Vetiver) grass, which are used on wastewater disposal sites. Treatments consisted of factorial combinations of $\mathrm{Na}$ and COD. Toxicity symptoms were not apparent below $16.2 \mu \mathrm{M} \mathrm{Na} / \mathrm{L}<5000 \mathrm{mg}$ COD $\mathrm{L}$, but were marked at $\geq 40 \mu \mathrm{M} \mathrm{Na} / \mathrm{L}$ and $\geq 15000 \mathrm{mg} \mathrm{COD} / \mathrm{L}$. Of the macrophytes, J. acutus was the least affected by high Na and COD levels. Averaged across the Na and COD treatments, total plant dry mass (DM) in the macrophytes peaked at $40 \mu \mathrm{M} \mathrm{Na} / \mathrm{L}$, as did ability to tolerate COD. The total $\mathrm{Na}$ in the top growth was greatest in J. acutus from which $61.4 \mathrm{mg} \mathrm{Na} /$ plant $\left(767 \mathrm{mg} / \mathrm{m}^{2}\right)$ could potentially be harvested after six months. Equivalent figures for $T$. latifolia and $S$. maritimus were 38.8 and $25.0 \mathrm{~g} / \mathrm{plant}$, respectively. Of the grasses, $P$. clandestinum produced 35\% more total DM than $V$. zizanioides. Top-growth Na contents were, respectively, 1427 and $29.1 \mathrm{mg} /$ plant. To maximise Na uptake in harvestable plant components, $J$. acutus should be planted in wetlands, and $P$. clandestinum in pastures used for wastewater disposal.
\end{abstract}

Wastewaters from wineries contain elevated concentrations of mineral elements, notably sodium (Na) (Van Schoor \& Rossouw, 2004). This is largely derived from cleaning and sterilising agents such as sodium hydroxide, sodium metasilicate and sodium carbonate (Papini, 2000). Winery wastewater also contains organic material (Shepherd, 1995), which confers high levels of chemical oxygen demand (COD) (Van Schoor, 2000). The disposal onto land or into streams of wastewater characterised by high $\mathrm{Na}$ concentrations and high COD values is regulated by the National Water Act (1998). Compliance invariably necessitates implementation of measures which reduce element concentrations and COD to acceptable levels before disposal. A method that has proved cost effective in South Africa (Mulidzi, 2008) and internationally (Bulc et al., 1997) is the treatment of wastewater in constructed wetlands. In such wetlands mineral elements are taken up by macrophytes (plants that grow in water but whose shoots project above the water surface) (Moshiri, 1993), a process known as phytoremediation (McCutcheon \& Schnoor, 2003). Some of the mineral elements taken up from water, sediment or soil (Moshiri, 1993; Salt et al., 1998), usually by the roots, are translocated to the shoots and reproductive structures (Wainio et al., 2003), together with which they may be removed by periodic harvesting. In addition to the removal of nutrient elements, macrophytes contribute to water purification by providing substrates and habitats where organic compounds may be broken down (Gale et al., 1994), reducing COD. Such breakdown is mainly brought about by microbes associated with the macrophyte root systems (Brix \& Carter, 1986).

Regardless of whether winery wastewaters undergo treatment or not, the water must be reused or disposed of. A common method is that of pasture irrigation (Mills et al., 2005). However, this practise may lead to increased soil salinity and sodicity, structural degradation, and the onset of anaerobic conditions in the subsoil (Van Schoor, 2000). A mitigating factor in such pastures is that plants may intercept and adsorb some of the minerals before they enter the soil (McCutcheon \& Schnoor, 2003). In constructed wetlands and disposal pastures effective phytoremediation necessitates the use of plants that are able to function in environments that may be acidic, nutritionally unbalanced, brackish and contain organic materials that contribute to high COD levels (Salt et al., 1998; Batty et al., 2002). Some plants reportedly flourish under these conditions, finding the wastewater a rich source of nutrients (Karpiscak et al., 1999). Others may lack adequately developed tolerance mechanisms and not flourish in such conditions (Marschner, 1995). Identification of suitable plants is therefore a necessity. Typha latifolia, an emergent wetland macrophyte (Quick, 1987), has already been used in wastewater treatment wetland trials (He \& Mankin, 1989; Moshiri, 1993; Zingelwa \& Wooldridge, 2009). Other potentially usable macrophytes are Scirpus maritimus and Juncus acutus. Typha species are found in a variety of often saline habitats throughout the world, and may have evolved a genetic potential to 
tolerate such conditions (Von Oertzen \& Finlayson, 1984). Juncus acutus and $S$. maritimus, however, are salt-marsh macrophytes. Both have been used in salt-tolerance studies (Coultas \& Hsieh, 1997). Scirpus maritimus is a facultative halophyte. It lacks morphological adaptations to salt tolerance, but is nevertheless able to accumulate $\mathrm{Na}$ (Kantrud, 1996). Scirpus maritimus ranked highly in sodium tolerance studies, and shows positive growth responses to $\mathrm{NaCl}$ (Ungar, 1991).

Since wastewater salt concentrations do not decrease appreciably during passage through constructed wetlands (Zingelwa \& Wooldridge, 2009), the plants used in disposal areas must, like those in artificial wetlands, be tolerant of poor water quality and able to take up minerals. Vetiveria zizanioides (vetiver grass) is widely used in hedges to alleviate erosion and improve soil structures in degraded land (Greenfield, 2002). Vetiveria zizanioides is tolerant of soil salinity, sodicity, and high heavy metal concentrations over a wide $\mathrm{pH}$ range (Greenfield, 2002), and tolerates up to $15 \% \mathrm{NaCl}$ (Nanakorn et al., 2005), whereas most plants have a threshold of $1 \% \mathrm{NaCl}$. When supplied with municipal effluent spiked with $\mathrm{NaCl}, V$. zizanioides plants thrived, due to the nutrients provided by the wastewater (Klomjek \& Nitisoravit, 2005). Another grass, Pennisetum clandestinum (kikuyu grass) is a common pasture crop that has been used in experiments to investigate tolerance and accumulation of salts (Mulidzi et al., 2002). In a study by Mills et al. (2005), P. clandestinum pastures irrigated with saline wastewater showed exceptional tolerance to salinity. Information concerning the tolerance of $P$. clandestinum to high COD levels is nevertheless sparse.

The objective of this work was to determine the relative abilities of certain macrophytes and grasses to survive, generate dry mass (DM), and accumulate mineral elements in environments containing a range of $\mathrm{Na}$ and $\mathrm{COD}$ concentrations.

\section{MATERIALS AND METHODS}

Cuttings of the macrophytes T. latifolia, J. acutus and S. maritimus, and of the grasses $P$. clandestinum and $V$. zizanioides were established in coarse sand in $40 \times 20 \times 20 \mathrm{~cm}$ cement troughs. These were arranged in a glasshouse using a design that made provision for a fully randomised trial in which each plant $\mathrm{x}$ water quality treatment was represented in two blocks. Each treatment received two L of a simulated winery wastewater twice each week. Wastewater treatments consisted of five concentrations of $\mathrm{Na}(0,16,40,162$ and $400 \mu \mathrm{M} / \mathrm{L})$, as in salinity tolerance trials by Marschner (1995), in factorial combination with five levels of COD (0, 5 000, 10 000, 15000 and $20000 \mathrm{mg} / \mathrm{L})$. The Na was derived from $\mathrm{NaCl}$, and the COD from distilled wine. The treated plants were allowed to grow for a six month period, by the end of which some of the shoots showed physiological responses to the treatments. Response severity was graded on a 4-point scale ( 0 , dead; 1 , weak shoots; 2 , shoots showing toxicity symptoms, die-back and necrosis apparent; 3 , all shoots green and apparently healthy). After grading, each plant was removed from the sand, quickly washed and divided into components (shoots, rhizomes [T. latifolia only] and roots). These were dried to constant mass $( \pm 1 \%)$ in a fan oven at $70^{\circ} \mathrm{C}$, weighed to determine $\mathrm{DM}$ and passed through a Wiley mill. A $0.40 \mathrm{~g}$ sample of each component was digested using a mixture of sulphuric acid and hydrogen peroxide (Allen, 1989). Concentrations of calcium (Ca), $\mathrm{Na}$, magnesium $(\mathrm{Mg})$ and potassium $(\mathrm{K})$ in the volumetric solutions were then determined using a Pye Solaar Atomic Absorption Spectrophotometer. Phosphorus (P) was determined by the method of Murphy and Riley (Olsen \& Sommers, 1982), using a Shimadzu spectrophotometer. Kjeldahl distillation and titration (Bremner \& Mulvaney, 1982) were used to quantify the nitrogen (N) contents. The DM and analytical data were subjected to an analysis of variance using SAS (SAS, 2003). Least significant difference (LSD) values were calculated at the $5 \%$ probability level to facilitate comparison between treatment means. Treatments which differed at $\mathrm{P}=0.05$ were regarded as significantly different. Co-efficients of determination $\left(\mathrm{r}^{2}\right)$ (Rees, 2001) were calculated to enable tissue element concentrations and DM's to be related to the concentrations of $\mathrm{Na}$ and COD in the treatment solutions.

\section{RESULTS AND DISCUSSION}

\section{Macrophytes}

\section{Physiological responses and survival}

From Table 1, it is apparent that there is a broad diagonal relationship such that the macrophyte shoots remained healthy where both $\mathrm{Na}$ and $\mathrm{COD}$ were low $(\leq 16 \mathrm{mM} / \mathrm{L} \mathrm{Na} ; \leq 5000$ $\mathrm{mg} \mathrm{COD} / \mathrm{L})$, whereas at high $\mathrm{Na}$ and COD concentrations $(\geq$ $40 \mathrm{mM} / \mathrm{L} \mathrm{Na}, \geq 15000 \mathrm{mg} \mathrm{COD} / \mathrm{L}$ ), most of the macrophyte plants died. In treatment combinations between these extremes, macrophyte shoot growth was generally weak or characterized by toxicity symptoms. This observation agrees with Xu et al. (2006), who found that high COD can cause shoot burning or even plant death, and with Marschner (1995) who commented that excess $\mathrm{Na}$ can stunt growth or even kill, either through its osmotic effect or through antagonism with essential mineral nutrients such as K and Ca. Dead S. maritimus, T. latifolia or J. acutus plants were observed in eight, four and three treatments, respectively. If the number of dead plants is regarded as an indication of ability to tolerate $\mathrm{Na}$ and $\mathrm{COD}$ in wetlands, then potential suitability for wetland use is likely to decrease in the sequence: $J$. acutus $>$ T. latifolia $>S$. maritimus. At all levels of COD, T. latifolia and $J$. acutus tolerated higher concentrations of $\mathrm{Na}$ than $S$. maritimus.

\section{TABLE 1}

Effect of sodium (Na) concentration and chemical oxygen demand (COD) on growth and survival of Typha latifolia, Scirpus maritimus and Juncus acutus. Visually evaluated after six months using the scale: 0 , dead; 1 , weak shoots; 2 , shoots showing toxicity symptoms; 3 , healthy shoots.

\begin{tabular}{ccccccc}
\hline $\begin{array}{c}\text { COD } \\
\mathbf{m g} / \mathbf{L}\left(\mathbf{x ~ 1 0} \mathbf{~}^{3}\right)\end{array}$ & Species & \multicolumn{5}{c}{$\mathbf{N a}(\boldsymbol{\mu M} / \mathbf{L})$} \\
& & $\mathbf{0}$ & $\mathbf{1 6}$ & $\mathbf{4 0}$ & $\mathbf{1 6 2}$ & $\mathbf{4 0 0}$ \\
\hline \multirow{2}{*}{0} & S. maritimus & 3 & 3 & 2 & 2 & 1 \\
& T. latifolia & 3 & 3 & 3 & 3 & 3 \\
& J. acutus & 3 & 3 & 3 & 3 & 2 \\
5000 & S. maritimus & 3 & 3 & 2 & 1 & 1 \\
& T. latifolia & 3 & 3 & 2 & 2 & 2 \\
& J.acutus & 3 & 3 & 3 & 2 & 2 \\
\multirow{3}{*}{10000} & S. maritimus & 2 & 2 & 2 & 1 & 0 \\
& T. latifolia & 3 & 2 & 2 & 1 & 1 \\
& J. acutus & 2 & 2 & 2 & 1 & 1 \\
& S. maritimus & 1 & 1 & 0 & 0 & 0 \\
& T. latifolia & 3 & 2 & 1 & 0 & 0 \\
& J. acutus & 2 & 2 & 1 & 1 & 0 \\
& S. maritimus & 1 & 0 & 0 & 0 & 0 \\
& T. latifolia & 1 & 1 & 1 & 0 & 0 \\
& J. acutus & 2 & 1 & 1 & 0 & 0 \\
\hline
\end{tabular}




\section{Dry mass production}

As was the case for potential suitability, total (whole plant) DM production decreased in the sequence: $J$. acutus $>$ T. latifolia $>$ S. maritimus (Table 2). Ideally, wetland macrophytes should retain most of their DM in the top growth, since this can be harvested without killing the plant (McCutcheon \& Schnoor, 2003). Relationships between shoot and below ground DM's were not consistent. Shoot DM in T. latifolia was lower than in the rhizome and root, whilst shoot DM was considerably smaller than root DM in $S$. maritimus. Only in J. acutus did shoot DM exceed root DM. Shoot DM was greatest in J. acutus and least in S. maritimus. Production of abundant shoot, relative to below ground biomass may indicate tolerance of high concentrations of elements, in water or sediments (Ye et al., 2001). If so, the fact that $J$. acutus was the only macrophyte in which shoot DM exceeded below ground DM may be further evidence in support of the suitability of this plant for use in wetlands used for the treatment of winery wastewater. The low total DM produced by $S$. maritimus, and its high mortality rate relative to T. latifolia and $J$. acutus, may indicate a higher level of physiological sensitivity to $\mathrm{Na}$ and COD. Such sensitivity would render $S$. maritimus relatively unsuitable for phytoremediation purposes.

\section{Tissue element concentrations}

With the exception of $\mathrm{Mg}$, which was low in $S$. maritimus, relative to $T$. latifolia and $J$. acutus, tissue element concentrations did not differ between macrophyte species (Table 2). In J. acutus, T. latifolia and $S$. maritimus, top growth $\mathrm{N}$ concentrations were low, and $\mathrm{P}, \mathrm{K}$ and $\mathrm{Na}$ were high, relative to the below ground structures.

\section{Total elements in plant}

Total element contents (DM x concentration) varied inconsistently with species, plant component and treatment with $\mathrm{Na}$ and COD (Table 2). Sodium decreased in the sequence $J$. acutus $>$ T. latifolia $>$ S. maritimus, whereas the $\mathrm{Ca}$ and $\mathrm{Mg}$ contents were greater in $T$. latifolia than in S. maritimus. Nitrogen was more abundant in T. latifolia and J. acutus than in S. maritimus, whereas $\mathrm{P}$ and $\mathrm{K}$ contents did not differ between species. Total shoot $\mathrm{K}, \mathrm{Ca}$ and $\mathrm{Na}$ exceeded that in the below ground plant components in all three species. Total plant $\mathrm{Na}$ peaked at $162 \mu \mathrm{M} \mathrm{Na} / \mathrm{L}$, and was lowest at zero $\mathrm{mg} \mathrm{COD} / \mathrm{L}$, tending to increase over the range from 5000 to $20000 \mathrm{mg} \mathrm{COD} / \mathrm{L}$.

\section{Effects of $\mathrm{Na}$ and $\mathrm{COD}$}

The effects of $\mathrm{Na}$ and COD on DM in the individual macrophytes were inconsistent. Where the macrophyte data were pooled (Table 3), there was a tendency for tolerance to COD, as indicated by DM production, to increase with $\mathrm{Na}$ to a maximum at $40 \mu \mathrm{M} / \mathrm{L}$, then decrease. Whole plant DM production at $40 \mu \mathrm{M} \mathrm{Na} / \mathrm{L}$ peaked at $15000 \mathrm{mg} \mathrm{COD} / \mathrm{L}$. These values $(40 \mu \mathrm{m}$ $\mathrm{Na} / \mathrm{L}$ and $15000 \mathrm{mg} \mathrm{COD} / \mathrm{L}$ ) may be close to the $\mathrm{Na}$
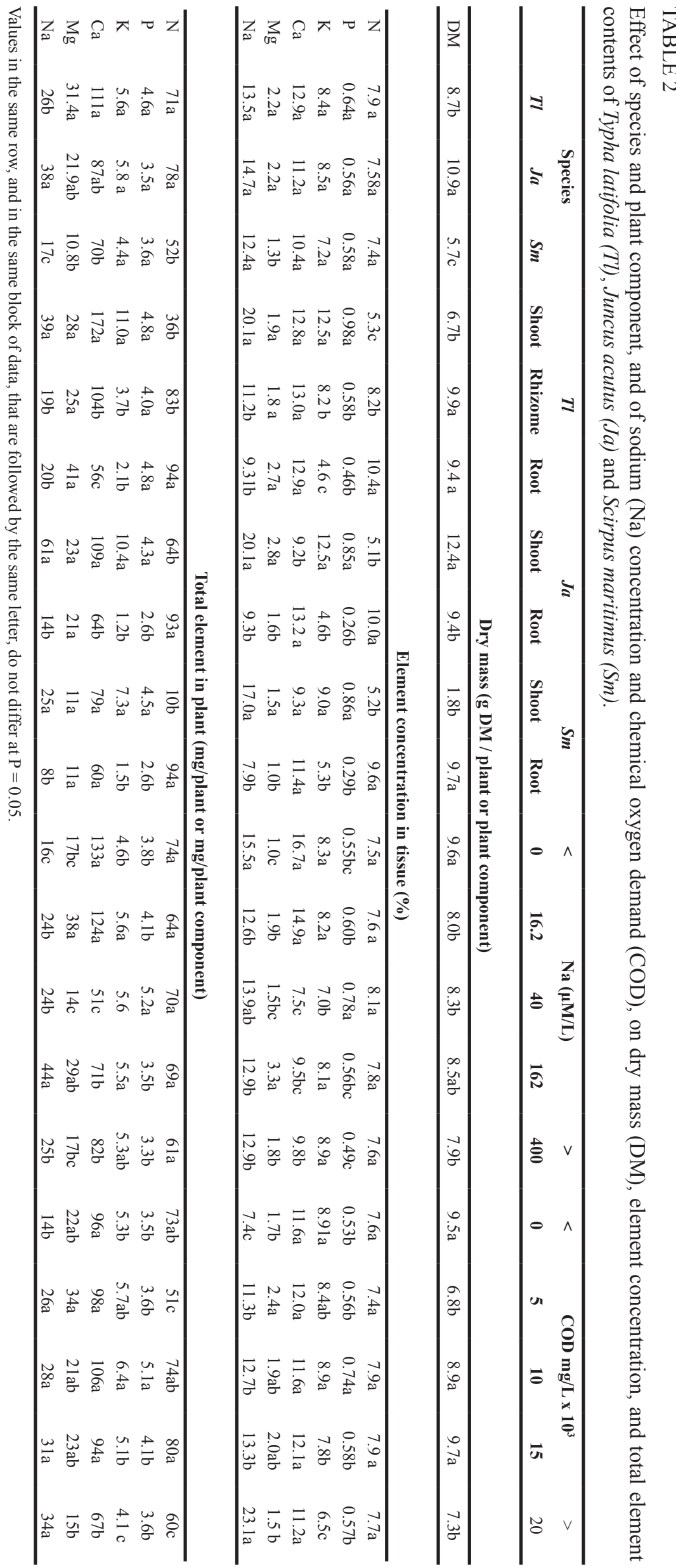
and COD concentrations in wetlands where such macrophytes are likely to perform best as agents of phytoremediation. The effects of $\mathrm{Na}$ on tissue element concentrations were either not significant or inconsistent, as were the effects of COD. The exception was tissue $\mathrm{Na}$, which was highest in the zero $\mu \mathrm{M} \mathrm{Na} / \mathrm{L}$ treatment, and which tended to increase with increasing COD. Coefficients of determination exceeded $0.5(50 \%)$ in the cases of $\mathrm{Na}$ in J. acutus and T. latifolia $\left(\mathrm{r}^{2}=0.54\right.$ in both), and total $\mathrm{Na}$ in $S$. maritimus $\left(\mathrm{r}^{2}\right.$ $=0.50$ ) (data not shown). Magnesium also correlated with the $\mathrm{Na}$ and COD treatments in $S$. maritimus $\left(\mathrm{r}^{2}=0.69\right)$. No other element was significantly related to the $\mathrm{Na}$ and $\mathrm{COD}$ treatments, implying the absence of a direct suppressive effect of the treatments on these elements, contradicting Marschner (1995).

Juncus acutus, with its combination of high shoot DM, reasonably high tolerance of $\mathrm{Na}$ and $\mathrm{COD}$, and high shoot $\mathrm{N}, \mathrm{P}, \mathrm{K}$ and $\mathrm{Na}$ concentrations, relative to the roots; plus its high total shoot $\mathrm{Na}(61.4 \mathrm{mg} / \mathrm{L})$ as compared with $25.0 \mathrm{mg} /$ plant in $S$. maritimus and $38.8 \mathrm{mg} / \mathrm{plant}$ in $T$. latifolia) (data not shown) was the best suited of the three macrophytes for use as a phytoremediant in wetlands. At a density of 12.5 plants $/ \mathrm{m}^{2}$, full harvesting of the top growth would result in the removal of $0.77,0.31$ and $0.49 \mathrm{~g} \mathrm{Na} / \mathrm{m}^{2}$ of wetland per harvest by J. acutus, S. maritimus and T. latifolia, respectively. These masses are small relative to the amount of $\mathrm{Na}$ that could enter a wetland, which explains why wetlands are not usually effective in removing $\mathrm{Na}$ (Zingelwa \& Wooldridge,

\section{TABLE 3}

Effect of sodium $(\mathrm{Na})$ concentration and chemical oxygen demand (COD) on dry mass production (g DM/plant) by Typha latifolia, Juncus acutus and Scirpus maritimus (data for the three species pooled).

\begin{tabular}{cccccc}
\hline $\begin{array}{c}\text { CODmg/ } \\
\text { L x 10 }\end{array}$ & $\mathbf{0}$ & $\mathbf{1 6}$ & $\mathbf{4 0}$ & $\mathbf{1 6 2}$ & $\mathbf{4 0 0}$ \\
\hline 0 & $13.63 \mathrm{a}$ & $6.08 \mathrm{c}$ & $6.53 \mathrm{~b}$ & $9.08 \mathrm{ab}$ & $12.7 \mathrm{a}$ \\
5 & $6.97 \mathrm{c}$ & $7.18 \mathrm{bc}$ & $6.75 \mathrm{~b}$ & $7.79 \mathrm{bc}$ & $5.48 \mathrm{c}$ \\
10 & $8.96 \mathrm{bc}$ & $10.84 \mathrm{a}$ & $6.86 \mathrm{~b}$ & $12.07 \mathrm{a}$ & $6.16 \mathrm{bc}$ \\
15 & $8.33 \mathrm{bc}$ & $9.54 \mathrm{ab}$ & $15.50 \mathrm{a}$ & $8.38 \mathrm{bc}$ & $7.04 \mathrm{~b}$ \\
20 & $10.34 \mathrm{~b}$ & $6.53 \mathrm{bc}$ & $5.71 \mathrm{~b}$ & $5.53 \mathrm{c}$ & 8.69 \\
\hline
\end{tabular}

Values in the same column, which are followed by the same letter, do not differ at $\mathrm{P}=0.05$

$\operatorname{LSD}(\mathrm{P}=0.05)=3.060$ (rows)
2009). A further drawback to harvesting top growth in wetlands is that any dead plant material that remains behind will decompose, promoting eutrophication (Quick, 1987).

\section{Grasses}

\section{Physiological responses and survival}

Neither of the grass species showed visible signs of physiological stress nor did the plants die (data not shown). Both P. clandestinum and $V$.zizanioides were therefore able to function across the range of $\mathrm{Na}$ concentrations, from zero to $400 \mu \mathrm{M} \mathrm{Na} / \mathrm{L}$, and from zero to $20000 \mathrm{mg} \mathrm{COD} / \mathrm{L}$ (data not shown).

\section{Dry mass production}

Pennisetum clandestinum produced 35\% more total plant DM (roots, rhizomes and shoots) than $V$. zizanioides (Table 4). Root DM in both grasses exceeded shoot DM. However, $P$. clandestinum exhibited a higher ratio of shoot DM to root DM (1:1.739) than $V$. zizanioides $(1: 1.391)$, which accords with the observation by Greenfield (2002) that $V$. zizanioides has a relatively well developed root system. In the grasses, total DM's tended to decrease with increasing solution $\mathrm{Na}$ concentration, in accordance with Marschner (1995). According to Chapman (1974), excess Na may affect the Ca regime in the plant, thereby inhibiting cell wall formation and membrane integrity, resulting in reduced growth. Total plant DM increased with both COD and $\mathrm{Na}$ over the respective ranges zero to $20000 \mathrm{mg} \mathrm{COD} / \mathrm{L}$ and zero to $40 \mathrm{mg} \mathrm{Na} / \mathrm{L}$. At higher $\mathrm{Na}$ concentrations $\mathrm{DM}$ was suppressed in the higher COD treatments (Table 5). Coefficients of determination $\left(\mathrm{r}^{2}\right)$ between total plant DM and the combined effects of $\mathrm{Na}$ and $\mathrm{COD}$ were not significant for either grass species (data not shown).

\section{Tissue element concentrations}

Concentrations of $\mathrm{N}, \mathrm{P}, \mathrm{Ca}, \mathrm{Mg}$ and $\mathrm{Na}$, but not $\mathrm{K}$, were significantly greater in $P$. clandestinum than $V$. zizanioides (Table 4). In P. clandestinum the concentrations of $\mathrm{N}, \mathrm{P}, \mathrm{K}, \mathrm{Mg}$ and $\mathrm{Na}$ in the shoots exceeded those in the roots whereas, in $V$. zizanioides the root $\mathrm{N}, \mathrm{Ca}$ and $\mathrm{Na}$ concentrations exceeded those in the shoots (Table 4). As with COD, the tissue N, P, K, Ca and Mg concentrations were lower at 162 and $400 \mu \mathrm{M} \mathrm{Na} / \mathrm{L}$ than in the zero (mg/L) Na, which agrees with Marschner (1995) and Chapman (1974). In contrast, tissue $\mathrm{Na}$ concentrations increased with increasing solution $\mathrm{Na}$ concentration. Chemical oxygen demand

\section{TABLE 5}

Parameter estimates and standard errors for regression relationships between dry mass (DM), tissue sodium (Na) concentration and total plant $\mathrm{Na}$, in the shoots of Pennisetum clandestinum as functions of solution $\mathrm{Na}$ concentration $(\mathrm{mM} / \mathrm{L})$ and solution chemical oxygen demand $(\mathrm{COD})(\mathrm{mg} / \mathrm{L})$. Model described by the relationship: $\mathrm{DM}, \mathrm{Na}$ conc., Total $\mathrm{Na}=\mathrm{a}+\mathrm{b}(\mathrm{Na}$ conc. $)+\mathrm{c}\left(\mathrm{Na}\right.$ conc. $\left.{ }^{2}\right)+\mathrm{d}(\mathrm{COD})+$ $\mathrm{e}\left(\mathrm{COD}^{2}\right)+\mathrm{f}(\mathrm{Na}$ conc. $\mathrm{x} \mathrm{COD})$.

\begin{tabular}{|c|c|c|c|c|c|c|c|c|c|}
\hline Parameter & & a (Intercept) & $\mathbf{b}$ & c & d & e & f & $\mathbf{P}$ & $\mathbf{r}^{2}$ \\
\hline \multirow{2}{*}{ DM (g/plant) } & Par. est. & 21.138 & 0.031 & $-1.183 \times 10^{-4}$ & $-1.796 \times 10^{-4}$ & $2.343 \times 10^{-8}$ & $6.646 \times 10^{-7}$ & \multirow{2}{*}{0.010} & \multirow{2}{*}{$28.2 \%$} \\
\hline & Std error & 2.371 & 0.027 & $6.145 \times 10^{-5}$ & $4.521 \times 10^{-4}$ & $2.111 \times 10^{-8}$ & $8.354 \times 10^{-7}$ & & \\
\hline \multirow{2}{*}{$\begin{array}{l}\text { Na concentration } \\
\left(\mathrm{mg} / \mathrm{kg}^{-1}\right)\end{array}$} & Par. est. & 26.461 & 0.557 & $6.132 \times 10^{-4}$ & $8.274 \times 10^{-4}$ & $5.543 \times 10^{-8}$ & $-6.010 \times 10^{-6}$ & \multirow{2}{*}{$<0.01$} & \multirow{2}{*}{$80.6 \%$} \\
\hline & Std error & 7.772 & 0.088 & $2.014 \times 10^{-4}$ & $1.480 \times 10^{-3}$ & $6.918 \times 10^{-8}$ & $2.740 \times 10^{-6}$ & & \\
\hline \multirow{2}{*}{$\begin{array}{l}\text { Total } \mathrm{Na} \text { in plant } \\
(\mathrm{mg} / \text { plant })\end{array}$} & Par. est. & 415.663 & 15.840 & -0.028 & -0.018 & $1.930 \times 10^{-6}$ & $1.360 \times 10-6$ & \multirow{2}{*}{$<0.01$} & \multirow{2}{*}{$94.5 \%$} \\
\hline & Std error & 262.234 & 2.966 & $6.800 \times 10^{-3}$ & 0.050 & $2.330 \times 10^{-6}$ & $9.239 \times 10^{-5}$ & & \\
\hline
\end{tabular}


did not affect the concentrations of $\mathrm{K}, \mathrm{Mg}$ and $\mathrm{Na}$ in the grasses. Contrary to Chapman (1974), the Ca concentration was low at zero $\mathrm{mg} \mathrm{COD} / \mathrm{L}$ relative to the higher COD treatments. Tissue $\mathrm{P}$ peaked in the $10000 \mathrm{mg} \mathrm{COD} / \mathrm{L}$ treatment, in which it was higher than in the zero and $20000 \mathrm{mg} \mathrm{COD} / \mathrm{L}$ treatments. Nitrogen concentrations did not differ over the range from zero to $10000 \mathrm{mg} \mathrm{COD} / \mathrm{L}$, but declined at higher COD's. In P. clandestinum, significant correlations $\left(\mathrm{r}^{2}\right)$ were observed between tissue N, P and Na concentrations and the combined effects of solution $\mathrm{Na}$ and COD (data not shown). Vetiver zizanioides showed no such significant relationships, implying that it is more likely to be effective in bringing about phytoremediation in disposal site pastures than P. clandestinum.

\section{Total elements in plants and plant components}

Total $\mathrm{P}, \mathrm{Ca}, \mathrm{Mg}$ and $\mathrm{Na}$, but not $\mathrm{N}$ and $\mathrm{K}$, were greater in $P$. clandestinum than $V$. zizanioides. The general tendency for $V$. zizanioides to contain lower masses of mineral elements than $P$. clandestinum therefore followed the same trend as mineral concentrations. Total $\mathrm{N}, \mathrm{Mg}$ and $\mathrm{Na}$ in the roots exceeded that in the shoots in P. clandestinum, whereas total root $\mathrm{N}, \mathrm{Ca}$ and $\mathrm{Na}$ exceeded that in the shoot of $V$. zizanioides. Total $\mathrm{P}$ in the shoots and roots did not differ in either species. Where both species were considered jointly, total N, P, K, Ca and $\mathrm{Mg}$ tended to drift irregularly downward with increasing solution $\mathrm{Na}$ concentration. The observed tendency for total $\mathrm{Ca}$ and $\mathrm{Ca}$ concentration to be low at high solution $\mathrm{Na}$ concentrations supports Chapman's (1974) contention that Na suppresses $\mathrm{Ca}$ uptake and $\mathrm{DM}$ production. In addition to $\mathrm{Ca}$, total $\mathrm{N}, \mathrm{P}, \mathrm{K}$ and $\mathrm{Mg}$ were significantly lower in the 400 than in the zero $\mu \mathrm{M} \mathrm{Na}$ treatment. As in the case of tissue concentration, total $\mathrm{Na}$ tended to increase with solution $\mathrm{Na}$. The effects of COD were less consistent. Total $\mathrm{Na}$ was unaffected by COD, whilst $\mathrm{Ca}$ tended to increase irregularly with COD. Total N, P, K, and Mg followed no specific sequence with increasing COD.

Of the grasses tested, $P$. clandestinum appears to be better suited than $V$.zizanioides for use in disposal areas receiving winery wastewaters, mainly because P. clandestinum produces more shoot DM (grazeable or harvestable top growth) than $V$. zizanioides (2.92 and $2.44 \mathrm{t} / \mathrm{ha}$, respectively, by extrapolation). Whereas the removal of $P$. clandestinum shoots and top growth from one ha removes $178.4 \mathrm{~g}$ of $\mathrm{Na}$ (at 12.5 plants $/ \mathrm{m}^{2}$ ), the removal of one ha of $V$. zizanioides top growth removes only $78.5 \mathrm{~g}$ of Na. Pennisetum clandestinum and $V$. zizanioides grasses removed from pastures used for the disposal of wastewaters over the range of compositions used in this trial can probably be used as fodder for cattle. Cattle consume salt liberally if given the choice, but are likely to stop if the concentration is too high

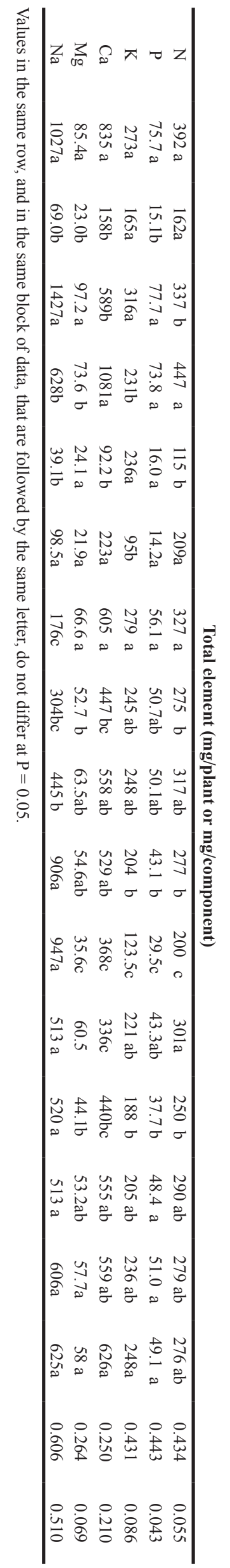


(C. Muller, personal communication, 2009). Grazing cattle on the pasture itself would result in $\mathrm{Na}$ being returned to the pasture in excreted material.

\section{Effects of $\mathrm{Na}$ and $\mathrm{COD}$}

In $P$. clandestinum, shoot $\mathrm{DM}$, shoot $\mathrm{Na}$ concentration and total shoot $\mathrm{Na}$ content were significantly affected by the $\mathrm{Na}$ concentration and COD treatments (Table 5). The relationships between shoot $\mathrm{Na}$ concentration and total shoot $\mathrm{Na}$ were characterised by higher $\mathrm{r}^{2}$ values than was shoot DM. The Na and COD treatments had no significant effects on root DM, root mineral concentrations or total root $\mathrm{Na}$ in P. clandestinum, or on shoot or root DM and mineral contents in $V$. zizaniodes (data not shown). Potential Na removal in harvested top growth can therefore be calculated from a bivariate second order polynomial function for P. clandestinum (presented in Table 5), but not for $V$. zizanioides, where the wastewater $\mathrm{Na}$ concentration and level of COD are known.

\section{CONCLUSIONS}

This trial was carried out in a glasshouse using simulated winery wastewater. The results must therefore be verified under field conditions. It is nevertheless apparent from the trial results that the macrophyte $J$. acutus is, potentially, a better alternative to T. latifolia for use in wetlands, and even more suitable than $S$. maritimus. However, none of the macrophytes tested removed appreciable amounts of $\mathrm{Na}$, or other elements, from the simulated winery wastewater. Post wetland disposal sites will therefore continue to receive mineral elements, notably $\mathrm{Na}$, though in slightly lower concentrations than would be the case if passage through a wetland were omitted. Since total plant DM production by wetland macrophytes varies with both $\mathrm{Na}$ concentration and level of COD in the environment, the efficiency of a wetland containing these macrophytes will vary with wastewater quality, and probably also with temperature and season. Collectively, these factors increase the need for pasture plants in disposal areas as second lines of defence against $\mathrm{Na}$ entry into the soil. Pennisetum clandestinum accumulates considerably more $\mathrm{Na}$ in the top growth, is more tolerant of high $\mathrm{Na}$ concentrations and high COD treatment levels than $V$. zizanioides, and may be a better alternative for use in areas receiving winery wastewater than $V$. zizanioides, as well as providing feed for cattle. It must nevertheless be emphasised that the combination of macrophytes in wetlands and grasses in disposal pastures is unlikely to take up more than a limited percentage of the $\mathrm{Na}$ in the wastewater. Further, after harvest, the Na-containing plant tissues must be disposed of in such a way that the Na will not contribute to increased sodicity elsewhere. It is better not to allow $\mathrm{Na}$ to enter the system in the first place. For this reason every effort should be made to substitute $\mathrm{Na}$-free products for those that contain $\mathrm{Na}$. Lowering COD levels, as by reducing the amounts of solids that enter the wastewater treatment system, may also minimise future problems with the treatment process, either in constructed wetlands or in post constructed wetland systems.

\section{LITERATURE CITED}

Allen, S.E., 1989 (2nd ed). Chemical analyses of ecological materials. Blackwell Scientific Publications, London.

Batty, L.C., Baker, A.J.M. \& Wheeler, B.D., 2002. Aluminium and phosphate uptake by Phragmites australis: The role of Fe, $\mathrm{Mn}$ and $\mathrm{Al}$ root plaques. Annals Bot. 89, 443-449.
Bremner, J.M., \& Mulvaney, C.S., 1982 (2nd ed, Part 2). Nitrogen-Total. In: Miller, R.H., Page, A.L. \& Keeney, P. (eds). Methods of Soil Analysis. American Society of Agronomy, Madison, pp 595-624.

Brix, H. \& Carter, V., 1986. An overview of the hydrologic concerns related to wetlands in the United States. Can. J. Bot. 64, 364-374

Bulc, T., Vrhovsek, D. \& Kukanja, V., 1997. The use of constructed wetland for landfill leachate treatment. Water Sci. Technol. 35, 301-306.

Chapman, V., 1974 (2nd ed). Salt marshes and salt deserts of the world. Verlag von J. Cramer, Germany.

Coultas, C.L. \& Hsieh, Y., 1997. Ecology and management of tidal marshes. CRC Press, London.

Gale, P., Reddy, K. \& Graetz, D.A., 1994. Phosphorus retention by wetland soils used for treated wastewater disposal. J. Env. Qual. 23, 370-377.

Greenfield, J.C., 2002. Vetiver grass: An essential grass for the conservation of planet earth. Infinity Publishers, Haverford.

He, Q. \& Mankin, K.R., 1989. Performance variations of COD and nitrogen removal by vegetated submerged reed wetlands. J. Am. Water. Res. Ass. 38, 16791689

Kantrud, H., 1996. The Alkali (Scirpus maritimus L.) and Saltmarsh (S. robustus Pursh) Bulrushes: a literature review. USGS publications. Downloaded on the 13/05/2009 from http://www.npwrc.usgs.gov/resource/plants/bulrush/index.htm.

Karpiscak, M.M., Wass, R.D., Freitas, R.J. \& Hopf, S.B., 1999. Constructed wetlands in Southern Arizona, Arid Lands Newsletter No.45:12. Downloaded on 26/03/2008 from http://ag.arizona.edu/OALS/ALN/aln45/wetlands.html.

Klomjek, A. \& Nitisoravit, L., 2005. Constructed wetlands: a study of eight plant species under saline conditions. Chemosphere 85, 585-593.

Marschner, H.,1995 (2nd ed). Mineral nutrition of higher plants. Academic Press, London.

McCutcheon, S.E. \& Schnoor, J.L., 2003. Phytoremediation: Transformation and control of contaminants. Wiley Publishing, London.

Mills, A.J., Fey, M.V. \& Johnson, C.E., 2005. Ionic strength as a measure of sulphate salinity stress: effects of sodium sulphate, sodium chloride and manganese sulphate on kikuyu (Pennisetum clandestinum) growth and ion uptake. S. Afr. J. Plant and Soil 21, 209-213.

Moshiri, G.A., 1993. Constructed wetlands for water quality improvement. Lewis publishers, Florida.

Mulidzi, A.R., Laker, M.C., van Schoor, L. \& Louw, K., 2002. Fate of organic components of winery effluents in soils. Wynboer 154, pp 82-83.

Mulidzi, A.R., 2008. Cost of a constructed wetland at Goudini distillery. Downloaded on the 4/02/2008 from Wynboer website, http://www.wynboer.co.za/ recentarticles/200802 cost.php3.

Nanakorn, M., Surawattananon, S. \& Wongwattana, C., 2005. In vitro induction of salt tolerance in vetiver grass. Downloaded on the 21/10/2009 from Vetiver organisation website http://www.vetiver.org

National Water Act, 1998. Republic of South Africa Government Gazette, 26 August.

Olsen, S.R. \& Sommers, L.E., 1982 (2nd ed, Part 2). Phosphorus. In: Miller, R. H, Page, A.L. \& Keeney, P. (eds) Methods of Soil Analysis. American Society of Agronomy, USA, pp 403-427.

Papini, A.G., 2000. Land treatment of grape processing effluents near Robertson, Western Cape, M. Sc. Thesis, Dept. of Geological Sciences, University of Cape Town, Cape Town, South Africa.

Quick, A.J.R., 1987. Typha latifolia, the bulrush - a literature review. City of Cape Town, Cape Town.

Rees, G.D., 2001. (2nd ed). Essential statistics. CRC Press Academy, London.

SAS Institute, Inc., 2003. Version 9.1.3. SAS Institute, SAS Campus Drive, Cary, North Carolina 27513.

Salt, D.E., Smith, R.D. \& Raskin, I., 1998. Phytoremediation. Annu. Rev. Plant Physiol. Plant Mol. Biol. 49, 643-668.

Shepherd, H.L.,1995. The use of constructed wetlands in winery process wastewater treatment. Downloaded on the 14/04/2009 from http://www.nccachmm.org/d7dmsum.html. 
Ungar, I.A., 1991. Ecophysiology of vascular plants. CRC Press, London.

Van Schoor, L., 2000. Management options to minimize negative environmental impacts at wine cellars. Downloaded on 6/05/2008 from http://www.wynboer. co.za/recentarticles/0700management.php3

Van Schoor, L.H. \& Rossouw, J., 2004. Guidelines for a winery wastewater and solid waste management plan. Wineland Magazine, March.

Von Oertezen, I. \& Finlayson, M., 1984. Wastewater treatment with aquatic plants: Ecotypic differentiation of Typha domingensis seedlings. Env. Pol. Series A 35, 259-269.

Wainio, S.E., Beckett, P.J., Pearson, D.A.B. \& Courtin, G.M., 2003. A potential remediation strategy using wetland vegetation and aquatic macrophytes in Kelley
Lake, Ontario. Downloaded on the 12/05/2009 from http://www.conama.cl/ especiales/1305/articles-31832_pdf_2do_inf_avnce.pdf.

Xu, Q., Nian, Y., Jin, X., Yan, C.C., Liu, J., \& Jiang, G., 2006. Effects of chitosan on growth of an aquatic plant (Hydrilla verticillata) in polluted waters with different chemical oxygen demands. J. Env. Sci. 16, 217-221.

Ye, Z.H., Cheung, K.C. \& Wong, M.H., 2001. Copper uptake in Typha latifolia as affected by iron and manganese plaque on the root surface. Can. J. Bot. 79, 314-320.

Zingelwa, N.S. \& Wooldridge, J., 2009. Uptake and accumulation of mineral elements from winery and distillery effluents by Typha latifolia and Phragmites australis. S. Afr. J. Enol. Vitic. 30, 43-48. 